\title{
Mortality Rates in Poultry Species and Categories during Transport for Slaughter
}

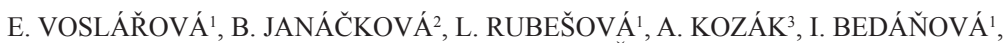 \\ L. STEINHAUSER ${ }^{1}$, V. VEČEREK ${ }^{1}$
}

\author{
${ }^{1}$ Department of Veterinary Public Health and Toxicology, Faculty of Veterinary Hygiene and Ecology, \\ University of Veterinary and Pharmaceutical Sciences in Brno, Czech Republic \\ ${ }^{2}$ Ministry of Agriculture, Czech Republic \\ ${ }^{3}$ Regional Veterinary Administration of the Capital Prague, Czech Republic
}

Received May 31, 2007

Accepted October 11, 2007

\begin{abstract}
Voslářová E., B. Janáčková, L. Rubešová, A. Kozák, I. Bedáňová, L. Steinhauser, V. Večerek: Mortality Rates in Poultry Species and Categories during Transport for Slaughter. Acta Vet. Brno 2007, 76: S101-S108.

Transport-related mortality rates were compared for various poultry species and categories where published data are limited. The numbers of broilers, hens and cockerels, turkeys, ducks, and geese transported for slaughter, and the numbers that died during such transport, were recorded from 1997 to 2006 in cooperation with the State Veterinary Administration of the Czech Republic. The mortality rate for individual poultry species and categories was calculated overall, and was also recorded for the following transport distances: up to $50 \mathrm{~km}$, from $51 \mathrm{~km}$ to $100 \mathrm{~km}$, from $101 \mathrm{~km}$ to $200 \mathrm{~km}$, from $201 \mathrm{~km}$ to $300 \mathrm{~km}$, and over $300 \mathrm{~km}$. Transport of poultry for slaughter was accompanied by varying mortality rates depending on poultry species and categories. The highest mortality rates occurred in hens and cockerels $(1.013 \%)$, followed by turkeys $(0.272 \%)$, broilers $(0.253 \%)$, ducks $(0.103 \%)$, and geese $(0.056 \%)$. Differences among the mortality rates estimated were highly significant $(p<0.001)$. Mortality rates highly correlated with transport distance. The lowest mortality rates were for the shortest transport distances: In broilers $(0.154 \%)$, turkeys $(0.164 \%)$, and hens and cockerels $(0.595 \%)$ for a transport distance up to $50 \mathrm{~km}$; and in ducks $(0.069-0.111 \%)$ and geese $(0.021-0.053 \%)$ for transport distances up to $300 \mathrm{~km}$. Highest mortality rates in hens and cockerels $(1.892 \%)$, turkeys $(0.341 \%)$, and broilers $(0.536 \%)$ were observed for transport distances over $200 \mathrm{~km}$, while in ducks $(0.147 \%)$ and geese $(0.253 \%)$, highest mortality rates were with transport distances exceeding $300 \mathrm{~km}$. The highest mortality rates for all transport distances were in hens and cockerels, followed by turkeys and broilers. The mortality rate in turkeys for a transport distance up to $50 \mathrm{~km}$ was significantly higher than that in broilers. No significant differences were found between mortality rates in turkeys and broilers for transport distances of 51-100 km and 101-200 km whereas, for a distance of 201-300 km and in distances exceeding $300 \mathrm{~km}$, the mortality rates in broilers were significantly higher compared to turkeys. The lowest mortality rates were observed in ducks and geese, with a significant difference between them only for transport distances of 51 to $100 \mathrm{~km}$, where the mortality rate in ducks was higher, and over $300 \mathrm{~km}$, where the mortality rate in geese was higher. When planning the transport of poultry for slaughter, susceptibility to stress induced by transport and transport distance (i.e. the duration of transport) of poultry species and categories should be considered.
\end{abstract}

Broiler chicken, hen, cockerel, turkey, goose, duck, mortality, poultry processing plant, transport distance

During loading and transport to a slaughterhouse, poultry are exposed to situations resulting in mortality: injuries, damage to health, and changes resulting from increased stress. Factors that affect mortality include the method of catching (Knierim and Gocke 2003; Nijdam et al. 2005), handling (Knowles and Broom 1990; Kettlewell and Mitchell 1994), thermal stress (MacCaluim et al. 2003), density, live weight, breed, time spent in transport, and lairage time at the processing plant (Warriss et al. 1992; Mitchell and Kettlewell 1998; Nijdam et al. 2004; Bedáňová et al. 2006, 2007; Voslářová et al. 2006a,b; Suchý et al. 2007).

Address for correspondence:

Ing. Eva Voslářová, Ph.D.

University of Veterinary and Pharmaceutical Sciences in Brno

Palackého 1-3

61242 Brno

Czech Republic

Tel.: +420 541562773
Fax: +420541562790
E-mail: voslarovae@ vfu.cz
http://www.vfu.cz/acta-vet/actavet.htm 
Mitchell and Kettlewell (1994) emphasise that the potentially harmful effects of adverse conditions during the transport are not only of political and public concern due to their consequences for animal welfare, but are also of economic importance with respect to increased losses and diminished quality of meat. A correlation between meat quality and exposure to preslaughter stress conditions has been demonstrated by Gregory (1996), Kannan et al. (1997), Owens and Sams (2000), Taubert et al. (2002), Debut et al. (2003) and others. In addition, the stress associated with transporting poultry prior to slaughter has been shown to increase endogenic contamination and consequently aggravate the microbial risk for the consumer of poultry meat (Mengert and Fehlhaber 1996; Mengert et al. 1998).

The mortality rate in poultry (particularly in broiler chickens) associated with transport to the slaughterhouse and preslaughter handling has been investigated by numerous authors. Nijdam et al. (2004) studied conditions influencing bruising and mortality of broilers during catching, transport and lairage. They reported the mean percentage of birds dead on arrival (DOA) as 0.46. Alshawabkeh and Tabbaa (1997), in a study of mortality and losses during transportation of broiler chickens from farms to processing plants in Jordan, found a mortality rate of $0.40 \%$. Tabbaa and Alshawabkeh (2000), in an examination of conditions, and the interaction of conditions, affecting preslaughter damage and mortality to broilers during transport, found a significant relationship between the time of year and mortality rate. Fries and Kobe (1992) reported transport-related mortality averages in broilers of $0.41 \%, 0.35 \%, 0.65 \%, 0.14 \%, 0.67 \%$ and $0.29 \%$ in individual flocks. Causes of trauma in broilers arriving dead at poultry processing plants were investigated by Gregory and Austin (1992). Their study found $0.19 \%$ dead on arrival. In the Czech Republic, Večerek et al. (2006a) found DOA rates of $0.247 \%$ for broilers. Voslářová et al. (2006c) reported a death rate of $0.279 \%$ in turkeys during transport, and Voslářová et al. (2007) reported a death rate of $0.925 \%$ in hens and cockerels transported to slaughter plants.

Death rates in poultry have been shown to be influenced by the distance transported. Warriss et al. (1990) looked at the time spent by broiler chickens in transit to processing plants. Warriss et al. (1992) investigated mortality in broiler chickens in relation to the length of journey to processing plants. In journeys lasting less than $4 \mathrm{~h}$, the incidence of dead birds was $0.156 \%$, for longer journeys the incidence was $0.283 \%$. Similarly, Warris s and Brown (1996) monitored the period of time needed to transport turkeys to processing plants, and found that birds were more likely to suffer from transport-induced stress during a long transit periods. Newberry et al. (1999) outlined welfare concerns associated with the transport of hens kept for commercial egg production that are slaughtered after the end of their economically viable life span.

The aim of this study was to examine differences in mortality rates during transport of broilers, mature chickens (hens and cockerels), turkeys, ducks, and geese for slaughter and to determine which of the poultry categories investigated was the most susceptible to stress due to transport. Further, efforts were made to discover if the differences in mortality rates within individual poultry species were related to transport distance.

\section{Materials and Methods}

The numbers of poultry (broilers, hens and cockerels, turkeys, ducks, and geese) dying as a result of transport (i.e. the numbers of poultry that died in vehicles or in slaughterhouses shortly after transport) were recorded during the period 1997-2006 in cooperation with the State Veterinary Administration of the Czech Republic.

The transport of all monitored poultry species and categories from rearing farms to slaughterhouses was accomplished using road vehicles. Transport distances were categorised as: up to $50 \mathrm{~km}, 51-100 \mathrm{~km}, 101-200 \mathrm{~km}$, $201-300 \mathrm{~km}$, and over $300 \mathrm{~km}$.

The average number of animals transported annually, and the average number dying as a result of transport, was recorded for individual poultry species and categories. On the basis of the results, the relationship between poultry species/categories and average transport-related mortality rates per year was calculated. 
The average number of dead poultry per year for distances up to $50 \mathrm{~km}, 51-100 \mathrm{~km}, 101-200 \mathrm{~km}, 201-300 \mathrm{~km}$, and for distances over $300 \mathrm{~km}$ was determined. On the basis of the results, the variation in transport-related mortality rates as a function of transport distance was calculated. These data were also recorded for individual poultry species and categories.

The results were processed with MS Excel using the statistical calculation module. Statistical processing was performed using the $\chi^{2}$ test, implemented in the Unistat 5.1 computer programme.

\section{Results}

The transport of 1,184.9 million broilers, 51.8 million hens and cockerels, 17.2 million turkeys, 0.768 million geese and 20.5 million ducks for slaughter was monitored from 1997 to 2006. Variation in transport-related mortality rates among poultry species and categories was recorded. The average numbers of transported and dead poultry per year are listed in Table 1.

Table 1. Overall transport-related mortality rates versus poultry species and categories in the period 1997-2006

\begin{tabular}{|l|c|c|c|}
\hline & & Average number per year & \\
\cline { 2 - 4 } & Transported birds & Dead birds & Mortality (\%) \\
\hline Broilers & 118493245 & 302684 & $0.253^{\mathrm{a}}$ \\
\hline Hens and cockerels & 5182069 & 49430 & $1.013^{\mathrm{b}}$ \\
\hline Turkeys & 1722725 & 4719 & $0.272^{\mathrm{c}}$ \\
\hline Geese & 76811 & 45 & $0.056^{\mathrm{d}}$ \\
\hline Ducks & 2052758 & 2096 & $0.103^{\mathrm{e}}$ \\
\hline
\end{tabular}

Explanatory notes: a,b,c,d,e $=$ statistical comparison - if the letters attached to particular values do not match, it indicates a significant difference at $p<0.05$; if the letters attached to particular values match, it means a nonsignificant difference, i.e. $p>0.05$, between poultry species and categories

Table 1 shows that individual poultry species and categories differed in transport-related mortality rates. The highest transport-related mortality rate was found in hens and cockerels $(1.013 \%)$, followed by turkeys $(0.272 \%)$, broilers $(0.253 \%)$, ducks $(0.103 \%)$, and geese $(0.056 \%)$. The differences between the mortality rates were significant.

The impact of distance on transport-related mortality for individual poultry species and categories was also investigated. The average number of transported animals per year for individual poultry species and categories for the transport distances monitored, is shown in Table 2. The average number of animals dying per year as a result of transport at the monitored distances is provided in Table 3 for individual poultry species and categories.

Table 2. The average numbers of birds transported annually to slaughterhouses for individual poultry species and categories for monitored transport distances

\begin{tabular}{|c|c|c|c|c|c|}
\hline $\begin{array}{c}\text { Transport distance } \\
(\mathrm{km})\end{array}$ & Broilers & $\begin{array}{c}\text { Hens } \\
\text { and cockerels }\end{array}$ & Turkeys & Geese & Ducks \\
\cline { 2 - 6 } & transported & transported & transported & transported & transported \\
\hline$<50$ & 50245622 & 1596023 & 548975 & 37368 & 601679 \\
\hline $51-100$ & 41251061 & 1304734 & 493017 & 19432 & 405657 \\
\hline $101-200$ & 23301249 & 1394239 & 307914 & 4028 & 918211 \\
\hline $201-300$ & 3234938 & 595928 & 214245 & 13318 & 116767 \\
\hline$>300$ & 460376 & 291146 & 158574 & 2664 & 10444 \\
\hline
\end{tabular}

The lowest mortality rates occurred at the shortest transport distances. The highest mortality rates in turkeys and hens and cockerels were found during transport distances of $201-300 \mathrm{~km}$, while broilers, ducks, and geese showed the highest mortality rate at distances over $300 \mathrm{~km}$. 
Table 3. The average annual transport-related mortality rates for individual poultry species and categories for the transport distances monitored

\begin{tabular}{|c|c|c|c|c|c|}
\hline \multirow{2}{*}{$\begin{array}{c}\text { Transport distance } \\
(\mathrm{km})\end{array}$} & Broilers & $\begin{array}{c}\text { Hens } \\
\text { and cockerels }\end{array}$ & Turkeys & Geese & Ducks \\
\cline { 2 - 6 } & Mortality $\%$ & Mortality $\%$ & Mortality $\%$ & Mortality \% & Mortality \% \\
\hline$<50$ & $0.154^{\mathrm{a}}$ & $0.595^{\mathrm{a}}$ & $0.164^{\mathrm{a}}$ & $0.053^{\mathrm{a}, \mathrm{b}, \mathrm{c}, \mathrm{d}}$ & $0.084^{\mathrm{a}, \mathrm{d}}$ \\
\hline $51-100$ & $0.280^{\mathrm{b}}$ & $0.766^{\mathrm{b}}$ & $0.297^{\mathrm{b}}$ & $0.021^{\mathrm{a}, \mathrm{b}, \mathrm{c}, \mathrm{d}}$ & $0.110^{\mathrm{b}}$ \\
\hline $101-200$ & $0.373^{\mathrm{c}}$ & $1.131^{\mathrm{c}}$ & $0.340^{\mathrm{c}}$ & $0.036^{\mathrm{a}, \mathrm{b}, \mathrm{c}, \mathrm{d}}$ & $0.111^{\mathrm{c}}$ \\
\hline $201-300$ & $0.535^{\mathrm{d}}$ & $1.892^{\mathrm{d}}$ & $0.341^{\mathrm{d}}$ & $0.045^{\mathrm{a}, \mathrm{b}, \mathrm{c}, \mathrm{d}}$ & $0.069^{\mathrm{a}, \mathrm{d}}$ \\
\hline$>300$ & $0.681^{\mathrm{e}}$ & $0.963^{\mathrm{e}}$ & $0.279^{\mathrm{e}}$ & $0.253^{\mathrm{e}}$ & $0.147^{\mathrm{e}}$ \\
\hline
\end{tabular}

Explanatory notes: ${ }^{\mathrm{a}, \mathrm{b}, \mathrm{c}, \mathrm{d}, \mathrm{e}}=$ statistical comparison - if the letters attached to particular values do not match, it indicates a significant difference at $p<0.05$; if the letters attached to particular values match, it means a nonsignificant difference, i.e. $p>0.05$, between transport distances for individual poultry species and categories

Table 4. Poultry species and categories versus the average transport-related mortality rate per year for transport distances up to $50 \mathrm{~km}, 51-100 \mathrm{~km}, 101-200 \mathrm{~km}, 201-300 \mathrm{~km}$, and over $300 \mathrm{~km}$

\begin{tabular}{|l|c|c|c|c|c|}
\hline \multirow{2}{*}{} & \multicolumn{5}{|c|}{ Transport distance (km) } \\
\cline { 2 - 6 } & $<50$ & $51-100$ & $101-200$ & $201-300$ & $>300$ \\
\cline { 2 - 6 } & Mortality (\%) & Mortality (\%) & Mortality (\%) & Mortality (\%) & Mortality (\%) \\
\hline Broilers & $0.154^{\mathrm{a}}$ & $0.280^{\mathrm{a}, \mathrm{c}}$ & $0.373^{\mathrm{a}, \mathrm{c}}$ & $0.535^{\mathrm{a}}$ & $0.681^{\mathrm{a}}$ \\
\hline Hens and cockerels & $0.595^{\mathrm{b}}$ & $0.766^{\mathrm{b}}$ & $1.131^{\mathrm{b}}$ & $1.892^{\mathrm{b}}$ & $0.963^{\mathrm{b}}$ \\
\hline Turkeys & $0.164^{\mathrm{c}}$ & $0.297^{\mathrm{a}, \mathrm{c}}$ & $0.340^{\mathrm{a}, \mathrm{c}}$ & $0.341^{\mathrm{c}}$ & $0.279^{\mathrm{c}, \mathrm{d}, \mathrm{e}}$ \\
\hline Geese & $0.053^{\mathrm{d}, \mathrm{e}}$ & $0.021^{\mathrm{d}}$ & $0.036^{\mathrm{d}, \mathrm{e}}$ & $0.045^{\mathrm{d}, \mathrm{e}}$ & $0.253^{\mathrm{c}, \mathrm{d}}$ \\
\hline Ducks & $0.084^{\mathrm{d}, \mathrm{e}}$ & $0.110^{\mathrm{e}}$ & $0.111^{\mathrm{d}, \mathrm{e}}$ & $0.069^{\mathrm{d}, \mathrm{e}}$ & $0.147^{\mathrm{c}, \mathrm{e}}$ \\
\hline
\end{tabular}

Explanatory notes: a,b,c,de = statistical comparison - if the letters attached to particular values do not match, it indicates a significant difference at $p<0.05$; if the letters attached to particular values match, it means a nonsignificant difference, i.e. $p>0.05$, in the column between poultry species and categories

Variation in average annual transport-related mortalities in poultry species and categories for transport distances up to $50 \mathrm{~km}, 51-100 \mathrm{~km}, 101-200 \mathrm{~km}, 201-300 \mathrm{~km}$, and over $300 \mathrm{~km}$ were calculated. The results are provided in Table 4.

At all transport distances, the highest mortality rates were shown to occur in hens and cockerels, followed by turkeys and broilers. Mortality rates in turkeys at distances up to $50 \mathrm{~km}$ were significantly higher than those of broilers. No significant differences between mortality rates in turkeys and broilers were found at transport distances of $51-100 \mathrm{~km}$ and $101-200 \mathrm{~km}$. However, at distances of $201-300 \mathrm{~km}$ and over $300 \mathrm{~km}$, mortality rates in broilers were significantly higher than those in turkeys. The lowest mortality rates were in ducks and geese, with a difference between them found at the transport distance of 51$100 \mathrm{~km}$, where the mortality rate in ducks was higher than that in geese, and at distances over $300 \mathrm{~km}$, where the mortality rate in geese was significantly higher than that in ducks.

\section{Discussion}

The mean percent of poultry DOA is a value that demonstrates deficiencies in poultry welfare during transport to processing plants. It is important both from the ethical standpoint, as an indicator of poor welfare during loading and transport, and also from an economic point of view as a loss to producers.

Stress factors for poultry in transport mentioned by various authors include the method of catching, handling, loading onto a vehicle, density, microenvironment in the transport vehicle, duration of transport and transport distance, driving style, unloading, and lairage time in processing plants, as well as season (e.g. Knowles and Broom 1990; Warriss et 
al. 1992; Kettlewell and Mitchell 1994; Mitchell and Kettlewell 1998; Knierim and Gocke 2003; MacCaluim et al. 2003; Nijdam et al. 2004, 2005; Bedáňová et al. 2006). The present investigation showed that differential susceptibility to stress in individual poultry species and categories was also a key factor contributing to transport-related mortality.

The data on the transport of poultry showed that the highest number of transported birds were domestic chickens, with broilers as the most numerous category within this species. In the monitored period, it was found that the average transport-related mortality rate per year in broilers was $0.253 \%$. This is a lower rate than the results reported by Nijdam et al. (2004) - 0.46\% DOA; Alshawabkeh and Tabbaa (1997) - 0.40\% DOA; and Fries and Kobe (1992) - 0.41, 0.35, 0.65, 0.67, and 0.29\% DOA. It is, however, a higher value than the rates reported by Gregory and Austin (1992) and Warriss et al. (1992) - 0.19 and $0.194 \%$ DOA, respectively. Significant differences in mortality rates were found among transport distance categories, with rates ranging from $0.154 \%$ to $0.681 \%$, the lowest mortality rates occurred over the shortest transport distance (up to $50 \mathrm{~km}$ ), and the highest mortality rates were seen for the longest transport distances (over $300 \mathrm{~km}$ ). These results corroborate the findings of Warriss et al. (1992), who noted that longer journeys to processing plants were associated with higher mortality in broiler chickens, and who reported mortality rates ranging from $0.156 \%$ to $0.283 \%$, depending on transport distance. The results of the present study indicate a substantially higher increase of DOA in broilers in relation to longer transport distances than that reported by Warriss et al. (1992). The results of investigations published by Večerek et al. (2006a) demonstrated that conditions under which broilers are shipped worsen with increasing transport distances. The fact that the mortality of broilers transported to processing plants showed an increasing trend during the monitored period is particularly alarming.

Of the categories monitored, hens and cockerels showed the highest transport-related mortality rate. An average of $1.013 \%$ of transported hens and cockerels died annually during transport to a slaughterhouse. The percentage of dead animals, for various transport distances, ranged from $0.595 \%$ to $1.892 \%$, with the lowest mortality rate occurring at the shortest transport distance (up to $50 \mathrm{~km}$ ) and the highest found at distances of 201-300 km. High transport-associated mortality rates in hens and cockerels were also reported by Voslářová et al. (2007). Not only is the DOA percentage in hens and cockerels several times higher than that of other monitored poultry species and categories, but it is also higher than mortality rates reported for other species of farm animals transported for slaughter in the Czech Republic. For example, the average transport-related mortality rate per year in pigs is $0.107 \%$ (Večerek et al. 2006c); in dairy cows, $0.038 \%$ (Večerek et al. $2006 \mathrm{~b}$ ); in fattened cattle, $0.007 \%$ (Malena et al. 2006); and in calves, $0.026 \%$ (Večerek et al. 2006d). Newberry et al. (1999) monitored DOA rates of hens transported for slaughter in Canada and the United States and observed that mortality ranged from $0.7 \%$ to $2.3 \%$ depending on the duration of the journey. These authors explained high mortality rates by claiming that relatively few poultry-processing companies are willing to accept spent hens because of their low meat value compared with broiler chickens and turkeys. For this reason, spent hens in Canada and the United states tend to be transported longer distances to slaughter than other types of poultry.

High mortality rates were also found in turkeys $(0.272 \%)$. One encouraging finding made by Vosláŕová et al. (2006c) is that the total mortality rate of turkeys during transport to slaughterhouses in the Czech Republic has been decreasing. The mortality rates in turkeys during the monitored period varied from $0.164 \%$ to $0.341 \%$, where the lowest and the highest mortality rates were found for transport distances up to $50 \mathrm{~km}$ and 201 $300 \mathrm{~km}$, respectively. As with hens and cockerels, the average mortality rate decreased for travel distance above $300 \mathrm{~km}$. This might be due to the factors that ensure a higher level 
of welfare for animals when transport is longer, as compared with that for the animals transported shorter distances. On the other hand, broilers, geese, and ducks showed the highest mortality rates when transported for the longest distance.

The lowest mortality rates were found in geese and ducks at all transport distances investigated. Mortality rates in geese and ducks varied from $0.021 \%$ to $0.253 \%$, and $0.069 \%$ to $0.147 \%$, respectively.

In conclusion, the currently used method of transport of poultry to a slaughterhouse was associated with mortality; with the highest mortality rates in hens and cockerels, followed by turkeys and broilers, and the lowest mortality rates found in ducks and geese. The number of poultry dying during transport to processing plants could be significantly reduced by a reduction in the transport distance. All monitored poultry species and categories showed significantly lower mortality rates at shorter transport distances. When planning the transport of poultry, transport distance and susceptibility to stress induced by transport in individual poultry species and categories should be considered.

\section{Vliv různých druhů a kategorií drůbeže na úhyny při přepravě na jatky}

Práce se zabývá porovnáním úhynů při přepravě na jatky mezi různými druhy a kategoriemi drůbeže, kde literární údaje jsou omezené. V období let 1997 až 2006 byly ve spolupráci se Státní veterinární správou České republiky zaznamenávány počty přepravených a počty uhynulých brojlerů, slepic a kohoutů, krůt, kachen a hus v souvislosti s přepravou na jatky. Byl sledován vliv druhu a kategorie drůbeže na úhyny při přepravě na jatky souhrnně a dále pro přepravní vzdálenosti do $50 \mathrm{~km}, 51 \mathrm{~km}$ až $100 \mathrm{~km}$, $101 \mathrm{~km}$ až $200 \mathrm{~km}, 201 \mathrm{~km}$ až $300 \mathrm{~km}$ a nad $300 \mathrm{~km}$. Přeprava na jatky je provázena úhyny u drůbeže a to rozdílně podle jednotlivých druhů a kategorií drůbeže. K největším úhynům dochází u slepic a kohoutů $(1,013 \%)$, dále u krůt $(0,272 \%)$, u brojlerů $(0,253$ $\%)$, u kachen $(0,103 \%)$ a hus $(0,056 \%)$. Mezi těmito úhyny byly zjištěny statisticky vysoce významné rozdíly $(p<0,001)$. Úhyny závisely na přepravní vzdálenosti. Ke statisticky nejnižším úhynům docházelo při nejkratších přepravních vzdálenostech: u brojlerů $(0,154 \%)$, u krůt $(0,164 \%)$, u slepic a kohoutů $(0,595 \%)$ při přepravní vzdálenosti do $50 \mathrm{~km}$, a u kachen $(0,069 \%$ až $0,111 \%)$ a hus $(0,021 \%$ až $0,053 \%)$ při přepravních vzdálenostech do $300 \mathrm{~km}$. Ke statisticky nejvyšším úhynům u slepic a kohoutů $(1,892$ $\%)$, krůt $(0,341 \%)$ a brojlerů $(0,536 \%)$ docházelo př́i přepravních vzdálenostech nad $200 \mathrm{~km}$, u kachen $(0,147 \%)$ a hus $(0,253 \%)$ při přepravních vzdálenostech nad $300 \mathrm{~km}$. Ve všech přepravních vzdálenostech k nejvyšším úhynům docházelo u slepic a kohoutů. Dále následovaly úhyny u krůt a brojlerů, kdy při přepravní vzdálenosti do $50 \mathrm{~km}$ byly statisticky významně vyšší úhyny u krůt, při přepravní vzdálenosti 51 až $100 \mathrm{~km}$ a dále 101 až 200 km nebyl mezi úhyny krůt a brojlerů statisticky významný rozdíl, a při vzdálenosti 201 až $300 \mathrm{~km}$ a nad $300 \mathrm{~km}$ jsou statisticky významně vyšší úhyny u brojlerů. Nejnižší úhyny byly u hus a kachen, mezi nimiž nebyl zjištěn u všech přepravních vzdáleností statisticky významný rozdíl, s výjimkou přepravní vzdálenosti 51 až $100 \mathrm{~km}$, kdy byl zjištěn vyšší úhyn u kachen, a dále s výjimkou přepravní vzdálenosti nad $300 \mathrm{~km}$, kdy byl zjištěn statisticky významně vyšší úhyn u hus. Při přepravě drůbeže na jatky je tak třeba zohlednit rozdílnou citlivost jednotlivých druhů drůbeže na stres spojený s přepravou a také vzdálenost - dobu přepravy.

\section{Acknowledgements}

Supported by the Research Project No MSM6215712402 "Veterinary aspects of food safety and quality".

\section{References}

ALSHAWABKEH K, TABBAA MJ 1997: Factors affecting mortality and losses during transportation of broiler chickens from farms to processing plants in Jordan. Dirasat Agric Sci 24: 53-61 
BEDÁŇOVÁ I, VOSLÁŘOVÁ E, VEČEREK V, PIŠTĚKOVÁ V, CHLOUPEK P 2006: Effects of reduction in floor space during crating on haematological indices in broilers. Berliner Munchener Tierarztl Wochenschr 119: $17-21$

BEDÁŇOVÁ I, VOSLÁŘOVÁ E, VEČEREK V, PIŠTĚKOVÁ V, CHLOUPEK P 2007: Haematological profile of broiler chickens under acute stress due to shackling. Acta Vet Brno 76: 129-135

DEBUT M, BERRI C, BAEZA E, SELLIER N, ARNOULD C, GUEMENE D, JEHL N, BOUTTEN B, JEGO Y, BEAUMONT C, LE BIHAN-DUVAL E 2003: Variation of chicken technological meat quality in relation to genotype and preslaughter stress conditions. Poult Sci 82: 1829-1838

FRIES R, KOBE A 1992: Data of flocks obtained in poultry meat processing (broilers). Dtsch Tierarztl Wochenschr 99: $500-504$

GREGORY NG 1996: Welfare and hygiene during preslaughter handling. Meat Sci 43(Suppl.S): S35-S46

GREGORY NG, AUSTIN SD 1992: Causes of trauma in broilers arriving dead at poultry-processing plants. Vet Rec 131: 501-503

KANNAN G, MENCH JA 1996: Influence of different handling methods and crating periods on plasma corticosterone concentrations in broilers. Br Poult Sci 37: 21-31

KANNAN G, HEATH JL, WABECK CJ, SOUZA MCP, HOWE JC, MENCH JA 1997: Effects of crating and transport on stress and meat quality characteristics in broilers. Poult Sci 76: 523-529

KETTLEWELL PJ, MITCHELL MA 1994: Catching, handling and loading of poultry for road transportation. Worlds Poult Sci J 50: 54-56

KNIERIM U, GOCKE A 2003: Effect of catching broilers by hand or machine on rates of injuries and dead-onarrivals. Anim Welf 12: 63-73

KNOWLES TG, BROOM DM 1990: The handling and transport of broilers and spent hens. Appl Anim Behav Sci 28: 75-91

MACCALUIM JM, ABEYESINGHE SM, WHITE RP, WATHES CM 2003: A continuous-choice assessment of the domestic fowl's aversion to concurrent transport stressors. Anim Welf 12: 95-107

MALENA M, VOSLÁŘOVÁ E, TOMANOVÁ P, LEPKOVÁ R, BEDÁŇOVÁ I, VEČEREK V 2006: Influence of travel distance and the season upon transport-induced mortality in fattened cattle. Acta Vet Brno 75: 619-624

MENGERT U, FEHLHABER K 1996: Investigations of the influence of premortal stress on the endogenic microbial contamination in broiler carcasses. Berliner Munchener Tierarztl Wochenschr 109: 28-31

MENGERT U, FEHLHABER K, ARWANA AA 1998: Investigating stress-induced endogenous microbial contamination of Muscovy ducks in connection with feeding Zinc-bacitracin. Arch Geflugelkd 62: 49-54

MITCHELL MA, KETTLEWELL PJ 1994: Road transportation of broiler-chickens - induction of physiological stress. Worlds Poult Sci J 50: 57-59

MITCHELL MA, KETTLEWELL PJ 1998: Physiological stress and welfare of broiler chickens in transit: Solutions not problems! Poult Sci 77: 1803-1814

NEWBERRY RC, WEBSTER AB, LEWIS NJ, VAN ARNAM C 1999: Management of spent hens. J Appl Anim Welf Sci 2: 13-29

NIJDAM E, ARENS P, LAMBOOIJ E, DECUYPERE E, STEGEMAN JA 2004: Factors influencing bruises and mortality of broilers during catching, transport and lairage. Poult Sci 83: 1610-1615

NIJDAM E, DELEZIE E, LAMBOOIJ E, NABUURS MJA, DECUYPERE E, STEGEMAN JA 2005: Processing, products, and food safety - Comparison of bruises and mortality, stress parameters, and meat quality in manually and mechanically caught broilers. Poult Sci 84: 467-474

OWENS CM, SAMS AR 2000: The influence of transportation on turkey meat quality. Poult Sci 79: 1204-1207

SUCHÝ P, BEDÁŇOVÁ I, VEČEREK V, VOSLÁŘOVÁ E, PIŠTĚKOVÁ V, CHLOUPEK P, VITULA F 2007: Effects of transport stress and floor space reduction on selected biochemical indices in common pheasant (Phasianus colchicus). Arch Geflugelkd 71: 56-61

TABBAA MJ, ALSHAWABKEH K 2000: Some factors affecting preslaughtering mortality and damage to broilers and interaction during transportation to processing plants. Dirasat Agric Sci 27: 375-384

TAUBERT E, WICKE M, VON LENGERKEN G, TROEGER K 2002: Relationship between external stress factors and meat quality of turkeys - Influence of external stress factors on the glycolysis. Fleischwirtschaft 82: $96-99$

VEČEREK V, GRBALOVÁ S, VOSLÁŘOVÁ E, JANÁČKOVÁ B, MALENA M 2006a: Effects of travel distance and the season of the year on death rates of broilers transported to poultry processing plants. Poult Sci 85: 1881-1884

VEČEREK V, MALENA M jr, MALENA M, VOSLÁŘOVÁ E, BEDÁŇOVÁ I 2006b: Mortality in dairy cows transported to slaughter as affected by travel distance and seasonality. Acta Vet Brno 75: 449-454

VEČEREK V, MALENA M, MALENA M jr, VOSLÁŘOVÁ E, CHLOUPEK P 2006c: The impact of the transport distance and season on losses of fattened pigs during transport to the slaughterhouse in the Czech Republic in the period from 1997 to 2004. Vet Med-Czech 51: 21-28

VEČEREK V, ŠÍMOVÁ V, MALENA M, VOSLÁŘOVÁ E, MALENA M jr 2006d: Effect of calf diseases on mortality during transport for slaughter. Acta Vet Brno 75: 625-630 
VOSLÁŘOVÁ E, BEDÁŇOVÁ I, VEČEREK V, PIŠTĚKOVÁ V, CHLOUPEK P, SUCHÝ P 2006a: Changes in haematological profile of common pheasant (Phasianus colchicus) induced by transit to pheasantry. Dtsch Tierarztl Wochenschr 113: 375-378

VOSLÁŘOVÁ E, HANZÁLEK Z, VEČEREK V, STRAKOVÁ E, SUCHÝ P 2006b: Comparison between laying hen performance in the cage system and the deep litter system on a diet free from animal protein. Acta Vet Brno 75: 219-225

VOSLÁŘOVÁ E, RUBEŠOVÁ L, VEČEREK V, PIŠTĚKOVÁ V, MALENA M 2006c: Variation in the mortality rate of turkeys during transport to the slaughterhouse with travel distance and month. Berliner Munchener Tierarztl Wochenschr 119: 386-390

VOSLÁŘOVÁ E, JANÁČKOVÁ B, VITULA F, KOZÁK A, VEČEREK V 2007: Effects of transport distance and the season of the year on death rates among hens and roosters in transport to poultry processing plants in the Czech Republic in the period from 1997 to 2004. Vet Med-Czech 52: 262-266

WARRISS PD, BEVIS EA, BROWN SN 1990: Time spent by broilers-chickens in transit to processing plants. Vet Rec 127: 617-619

WARRISS PD, BROWN SN 1996: Time spent by turkeys in transit to processing plants. Vet Rec 139: 72-73

WARRISS PD, BEVIS EA, BROWN SN, EDWARDS JE 1992: Longer journeys to processing plants are associated with higher mortality in broiler-chickens. Br Poult Sci 33: 201- 206 